\title{
Odd Fish Finish First
}

Imagine a big glass tank loaded up with hundreds of squirmy gold fish. Pick the one you want and in seconds you've lost it because they all look alike. Suddenly, behind the coral tree, from within the school of many, emerges a slim, purple and orange fish. He quickly stands out from the group, his distinctiveness apparent. He swims around with a unique confidence and a bold identity, while the others just seem to fade away.

Odd fish are memorable. Odd fish command a premium price. Odd fish exude added dimensions of value. Odd fish finish first.

In business, understanding this metaphor is the difference between drowning in a sea of sameness and being a great brand. Jack Trout (speaking of smart fish) noted in his bestselling book "Differentiate or Die" that choosing among multiple options is always based on differences, implicit or explicit. Psychologists point out that vividly differentiated characteristics anchored to a product can enhance the public's memory of it because they have added uniquely to the mind of the consumer. In other words, if you are promoting a product or service, give the consumer a reason to choose it. This concept is so simple, yet many business leaders struggle with applying it to their brands. The problem starts with defining what distinction truly is and is not. Distinction is not that you love or care for your customers more than your competition does. It's not that you are a one-stop shop or even that your product or service is of the highest quality. Those are all vital attributes, but they are also likely touted by 90 percent of the competitive players in your category.

Distinction in branding is something that you do so well and often that it is truly different and has become your asset - so much so that your competition would be unlikely to try to mimic your actions. It's something that your buyers identify as really unusual and, as a result, award your brand extra space in their info-aged, over-crowded minds.

Developing a platform of distinction requires courage by leadership. Doing things differently can draw out herds of critics, from customers to employers to industry players. That's to be expected, because new or different requires the adoption of new thinking and it's human nature to resist it for some time. Have faith and believe in your oddness. Believe in your brand.

\section{Take the test:}

How distinct is your brand? Are you an odd fish that stands out or are you simply one of many in a school of fish?

- Visually, does your brand look different than your competitors?

- If you covered up your logo on your brochures and Web site with only the content visible, would anyone know it's your brand?

- Does everyone in your organization know how you're different?

If you answered "no" to even one of these, you've got work to do. As you explore points of distinction for your brand, ask yourself about:

- Your market: What's relevant to the needs and desires of your customers?

- The competitive landscape: Are any of your competitors occupying this space (point of 
difference?)

- Social and world conditions: Are there current events, attitudes or recent wounds from an issue that would prohibit open acceptance of your point of difference?

- Copycat protection: Can someone easily copy or imitate your point of difference?

- Longevity: Will this point of difference be sustainable for a substantial period, get better with age, or quickly become irrelevant and out of style?

- Can the dog hunt? Does this point of difference have the legs to carry the brand? Can it be leveraged by many communication vehicles?

26 ways to Think Like The Odd Fish:

- Make up a word for a service

- Use different ingredients

- Sport an odd uniform

- Do it faster

- Save the earth while you are at it

- Add humor

- Package it in the unexpected

- Give something big away

- Offer an unbelievable guarantee

- Gift often

- Be exclusive

- Create a mascot

- Charge a lot more

- Take alternative payments

- Reward loyalty with living gifts

- Get social

- Make a metaphor

- Rearrange it

- Sacrifice something important

- Break the rules

- Always have a deadline

- Conduct an annual poll

- Super-size it

- Get nostalgic

- Exaggerate

- Simplify the process 
Consumers are smothered with more than 5,000 brand messages every day. The marketplace is cluttered, with many excellent options offered. If you want to make the buyer's choice easy and finish first, you've got to be truly distinct and communicate those unique attributes at all touch points every day. The services and products space is very competitive. To find your distinct calling, you must look deep inside your organization and explore all your branding touch points. Think about your processes, your communication and your services. The possibilities are endless.

\section{Author}

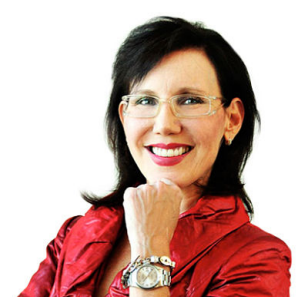

Karen Post is an international branding speaker, consultant and business authority. Her expertise focuses on branding, entrepreneurial, social media and women's business issues. As a recognized branding expert and social media pioneer, she has appeared on worldwide print, broadcast and online media and is the author of Brain Tattoos: Creating Unique Brands That Stick in Your Customers' Minds and is an active blogger. Karen can be reached through her blog www.oddpodz.com or by emailing her at Kp@brandingidva.com.

This article was uploaded to http://www.languageatwork.eu in December of 2010 and published under a "Creative Commons license Attribution Non-commercial No derivatives (cc by-nc-sa)" for more information please go to: http://creativecommons.org/about/license/ 